\title{
FOUCAULT E A EDUCAÇÃO: FASCINANTES DESAFIOS - JENNIFER M. GORE
}

\begin{abstract}
Juliana da Silva Passos ${ }^{1}$
Nenhum discurso é inerentemente libertador ou opressivo. A condição libertadora de qualquer discurso teórico é uma questão de investigação histórica, não de proclamação teórica (Jana Sawicki, 1988a, p. 166, in: Gore, 1994, p. 9)
\end{abstract}

O texto de GORE (1994) tem como objetivo declarado defender e demonstrar a importância desta posição no campo da educação, embasando-se no trabalho do filósofo social Michel Foucault, explorando as conseqüências da visão deste de que a verdade e o poder estão mutuamente ligados através de práticas específicas.

Segundo Focault, a 'verdade' está circularmente ligada a sistemas de poder. Estes sistemas de poder produzem e apóiam estas 'verdades' que alimentam os sistemas de poder. Desta maneira, os regimes de verdades não estão ligados mais apenas aos discursos “dominantes" ou "dominadores". Se verdade e poder estão ligados de maneira circular, então todos os discursos podem ser vistos funcionando como regimes de verdade.

Para compreender melhor a noção de regime de verdade, faz-se relevante trabalhar com os conceitos de poder e saber foucaultianos. A este se atribui equivocadamente a idéia de que "saber é poder" ou "poder é saber", enquanto que o mérito de Foucault foi o de estudar a relação entre eles. Neste processo, distancia-se da concepção convencional na qual o poder exerce um papel necessariamente negativo e o saber pode desestruturar a dominação do poder repressivo, servindo de arma aos males do poder. Ao contrário desta idéia, presente em muitos discursos educacionais ditos "radicais", que pretendem através da conscientização revelar 'a verdade'para derrubar o poder, a perspectiva foucaultiana desafia a suposição de que alguma verdade não-distorcida possa ser acessada. O poder, não é necessariamente repressivo, uma vez que incita, induz, facilita ou dificulta, amplia ou limita e é exercido em vez de possuído e, assim, circula.

Em sua análise do poder, Foucault está especialmente interessado nas formas de governo. Governo, não se limitando a idéia de administração do estado ou estruturas políticas, mas no sentido mais amplo, em que governar é estruturar o campo possível de ação dos

\footnotetext{
${ }^{1}$ Juliana Passos é mestranda em Estudos Literários na UFPR.
} 
outros. A respeito disto, revela-se uma significativa mudança na moderna forma de governar. Enquanto que tradicionalmente o poder é o que é visto, é o que está em foco, como em um governo monárquico, na modernidade encontraremos o poder disciplinar, um poder invisível e internalizado que bota os sujeitos em evidência. Esta "iluminação", o fato de poder ser constantemente visto, observado, vigiado, induz no indivíduo um estado consciente e permanente de visibilidade, assegurando o funcionamento automático do poder.

A pedagogia se baseia em formas particulares de governo, cujo desenvolvimento pode ser traçado historicamente, e produz e reproduz regras e práticas particulares. No contexto da educação escolar, o poder disciplinar explicaria a auto-regulamentação dos estudantes: tem-se enfatizado cada vez mais o autodisciplinamento. Seguindo Foucault, as práticas que induzem este comportamento são chamadas tecnologias do $e u$, que agem sobre o corpo, produzindo regimes político-corporais particulares. Nessa análise, as pedagogias funcionam como regimes de verdade, tendo em seus processos as relações disciplinares de poder-saber como peças fundamentais. Para Foucault, uma relação de fiscalização, definida e regulada não é adjacente, mas parte essencial da prática de ensino, inerente e que multiplica sua eficiência. Regimes de verdade não seriam propriamente negativos, mas antes de tudo necessários.

Por outro lado, as relações de poder-saber se constroem no plano discursivo, o que faz com que o vínculo nunca seja garantido. O discurso é ambíguo e pode ligar-se tanto a estratégias de dominação quanto de resistência. O discurso que torna possível o vínculo poder-saber, também o mina. Sem ser inerentemente nem fonte de dominação, nem fonte de resistência, a pedagogia não está nem fora do poder, nem circunscrita por ele, sendo mais como a própria arena da luta, pois, se as relações de poder são dispersas e fragmentadas, qualquer prática é capaz de tornar-se fonte de resistência ou de repressão, o que nos estimula a sermos mais humildes e reflexivos em nossas práticas pedagógicas.

Coerente e realista, Jennifer Gore aponta justamente para aquilo que Foucault e as teorias ditas pós-estruturalistas podem trazer de melhor para a educação, equilibrando duas grandes tendências perigosas que dividem o pensar da educação. De um lado, uma crença ilusória de uma pedagogia de tendências marxistas que se acredita libertadora de todas as opressões e reveladora da verdade. De outro lado, pensadores pós-estruturalistas relativistas radicais completamente descrentes da educação tal qual a entendemos hoje e partidários da total desconstrução do que entendemos por escola, sem ao menos sugerir o que ficaria em seu lugar. Gore consegue conciliar o que realmente podemos aproveitar das duas tendências, 
sendo fiel ao que de fato Foucault propõe - a necessidade e o valor social positivo da escola, mas sem idealizações, tendo a honestidade e humildade de perceber sua fragilidade inerente frente à realidade de que não existe uma realidade objetiva, mas construções discursivas e históricas de poder e saber que constroem realidades relativas.

\section{REFERÊNCIA}

GORE, Jennifer. Foucault e a educação: fascinantes desafios In: SILVA, Tomaz T. da. (Org.). O sujeito da educação: estudos foucaultianos. 2 ed. Petrópolis: Vozes, 1994. p. 9-20. 